\title{
COMPARISON BETWEEN SOME PROPOLIS PHENOLIC COMPONENTS IN EGYPT
}

\author{
GHANIA, A.M.M. ${ }^{1}$, NAGLAA E. GHAZALA ${ }^{1}$, M. A. I. ABDEL-AZEIM ${ }^{1}$, \\ A. R. MAZEED ${ }^{1}$ and S. H. RAMDAN ${ }^{2}$
}

1. Dept. of Apiculture, Plant Protection Research Institute, Agriculture Research Center, Dokki, Cairo, Egypt ${ }^{1}$.

2. Kingdom of Bee, Fac. of Agric., Ain Shames Univ².

(Manuscript received 4 April 2018)

\begin{abstract}
$\mathrm{P}$ ropolis samples of different regions in Egypt, added to commercial Chinese propolis were tested to determine their phenolic compounds present in each using HPLC analysis and through Ethanolic and water extract methods. The results obtained revealed presence 12 phenolic compounds in the tested samples on more distributed between them with different concentsration and percent. The ellagic acid recorded the highest percent in the propolis Kfer- Elsheikh governorate $(80 \%)$ followed by Qalubiasame collected from Kafer $(60 \%)$, respectively. While with commercial Chinese it not recorded at all, and considers the very poor phenolic compounds, as well as it characterized by presence a higher percent of cinamicacid. The water propolis extract of old bee wax combs reveal presence a little amounts of twelve phenolic compounds, the highest of them was benzoic acid (60\%).
\end{abstract}

\section{INTRODUCTION}

Propolis is a natural product derived from plant resins and collected by honey bees to seal the walls and entrance of the hive and contributes to protect the colony against different pathogens (Ghisalberti, 1979). Each region and colony seems to have its own preferred resin sources, which results in large variation of final composition. In Europe, honeybees preferably collect resins from leaf buds of Populus species (Krell,1996). The composition of propolis variety and depends on the environmental plants, differences in color, odor and chemical compounds are noticed relying on the source and the season of gathering (Souza et al., 2016). Phenolic compounds are a wide topping of plant accessories metabolites, showing a variety of structures including phenolic acids, flavonoids, lignans, quinones, tannins, coumarins and others (Huang et al., 2010).It's owns several biological properties such as antibiotic, antifungal, antiviral and have aanti-inflammatory activities (Santos et al., 2003). Furthermore, different compositions and amounts of the active substances are detected in separate samples of propolis (Bankova et al., 2002). The variety chemical compositions and biological activities of propolis are due to geographical location, plant sources and collecting season, therefore in ancient era, Egyptians, Greeks and Romans used propolis as a medication against some diseases (Sforcin and Bankova 
2011). The therapeutic properties of propolis are due to its chemical composition with bioactive compounds; thus, researchers are interested tostudy it's chemical composition and biological properties (Bankova 2005). The volatile substances (aromatic oils) determine the flavor of propolis, and the variety of flavor depends on the geographical area and assortment of plants (Bankova, et al., 1994)). Furthermore, propolis has been found to contain phenolic acids (for example, phenolic derives of cinnamic and coumaric acids), characterized by very potent antimicrobial activity (Hegazi et al., 2000). The antimicrobial and anti-inflammatory activity of European propolis is associated with the presence of flavonoids, flavones, and phenolic acids and their derives (Bankova, 2005). Flavonoids, phenolic, diterpenoid acids, aromatic acids, and triterpenoids compounds are the major components of propolis (Kumazawa et al. 2008). The aim of this ivestigation is to determine the phenolic contents indefferent sources of propolis and the effect of this contents on its quality.

\section{MATERIALS AND METHODS}

This work was done in the year of (2017). Four propolis samples were collected from the apiaries of Kfer- Elsheikh and ElQalubia governorates, as well as commercial Chinese propolis added to propolis collected from oldbeewaxcombs. Ethanolic and water extract were done according to method of Iidenize et al., (2004) as follows; The Ethanolic extract was carried out by dissolving $10 \mathrm{~g}$. of the propolis samples in $100 \mathrm{ml}$ of the Ethanol $(80 \% \mathrm{v} / \mathrm{v})$ for 7 days then filtered and dried. The propolis water extract was done only on the old wax combs.

\section{Determination of propolis phenolic compounds by HPLC a- Instrument used:}

Agilent 1260 infinity HPLC Series (Agilent, USA), publication number 59913801 EN ,2014. equipped with quaternary pump, a Zorbax Eclipse plus $C_{18}$ column $100 \mathrm{~mm} \times 4.6 \mathrm{~mm}$ i.d., (Agilent technologies, USA), operated at $25 \mathrm{C}$. The $05 \mathrm{uz}$ is achieved using a ternary linear elution gradient with (A) High Performance Liquid chromatography (HPLC) grade water $0.2 \% \mathrm{H}_{3} \mathrm{PO}_{4}(\mathrm{v} / \mathrm{v}),(\mathrm{B})$ methanol and (C) acetonitrile. The injected volume was $20 \mu \mathrm{L}$. Detection: VWD detector set at $284 \mathrm{~nm}$. Environmental condition: Temperature: $23^{\circ} \mathrm{C}$ and humidity: $40 \%$.

\section{B- Test method;}

$1 \mathrm{~g}$ of extract was propolis was soaked in50 $\mathrm{ml}$ methanol $80 \%$ overnight then centrifuged for $20 \mathrm{~min}$ at $4000 \mathrm{rpm}$. The supernatant evaporated till dryness then dissolved in $5 \mathrm{ml}$ methanol UPLC grade filter thtough 0.45 um PTFE syringe filter. 


\section{RESULTS AND DISCUSSION}

The Ethanolicproplis extract collected from kafr Elshiekh showed present 11phenolic compounds. The ellagic acid recorded The higest percent of them $(53.45 \%)$, while same from Qalubia governorate recorded seven phenols The highest of them was the ellagic acid too $(80.60 \%)$ at same time proplis from kschataerized by presence a benzoic and vanillic acids whis percent (20\%,20.33\%),respectively. In contrast the water extract old wax combs showed high benzoic acid contration (61.5\%) followed with benzoic 1.2 diop (10.5\%), and caffeine (9\%), Its notcable to not that water extract old wax combs showed little amoung of 12 phenolic compounds in comparisonTo same of kafer Elshik and Qulubia governoments. The benzoic acid recorder the higher percent (61.5\%). The commercial chinesepropolisrecorded only five phenolic compounds with a little amounts of them and consider the most propolis of the phenolic components. The Cinnamic acid showed the highest percent of them $(92.41 \%)$.

It could be summarized that the following results; Propolis samples of different regions of Egypt, added to commercial Chinese propolis were tested to determine their phenolic compounds present in each using HPLC analysis and through ethanolic and water extract methods. The results obtained revealed presence 12 phenolic compounds in the tested samples on more distributed between them with different concentration and percent. The ellagic acid recorded the highest percent in the propolis Kfer- Elsheikh governorate (80\%) followed by Qalubia same collected from Kafer $(60 \%)$, respectively. While with commercial Chinese it not recorded at all, and considers the very poor phenolic compounds, as well as it characterized by presence a higher percent of cinamicacid. The water propolis extract of old bee wax combs reveal presence a little amounts of twelve phenolic compounds, the highest of them was benzoic acid (60\%).

From results obtained it could be decided that Egyptian propolis was the best content phenolic compound. compared with the commercial chinesepropolis. In addition that water extract of old bee wax combs contains all phenolic compound tested by a little amounts. It can be advice to gone both of Ethanolic and water extracts because they detected all tested phenolic compounds. 


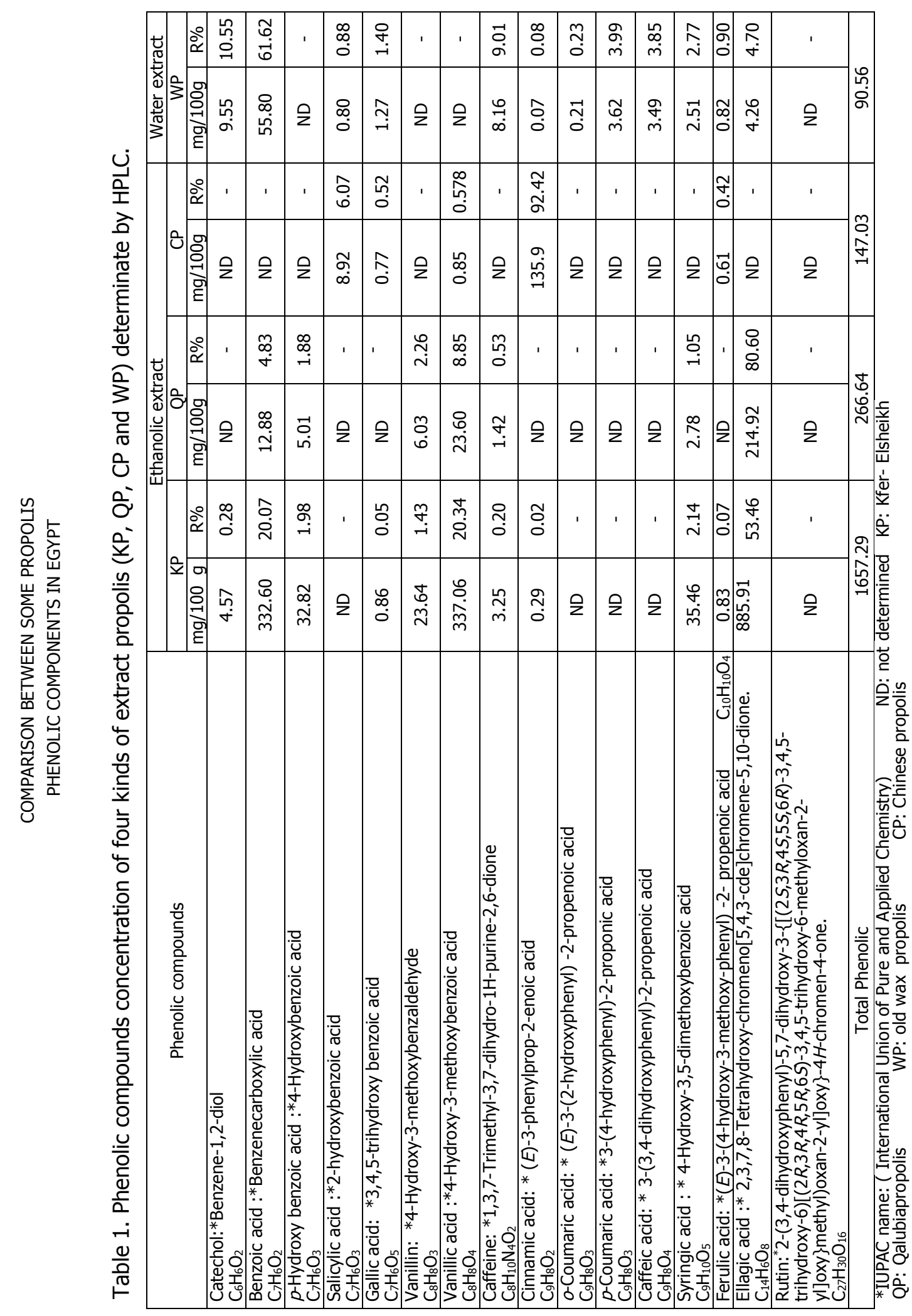


The findings of various studies confirm that chemical composition of propolis depends on trees and plants available to the bees, on the season in which it is collected, on the geographical area, and other factors (Kartal et al., 2002). The variety temperate zone and plant sources propolis is generally referred as poplar propolis because mainly produced from the bud exudates of Populus trees (Popova et al., 2004). Birch propolis is found specifically in Russia and is different from poplar propolis (Christov et al., 2006). Various forms of Brazilian propolis are available: green propolis is derived from Baccharisdracunculifornia (Righi et al., 2011). while brown propolis comes from Copaifera species (Sawaya et al., 2006) and red propolis is obtained from Dalbergiaecastophyllum L. (Piccinelli et al., 2011). Different compositions and amounts of the active substances are detected in separate samples of propolis (Bankova et al., 2002). Obviously, the chemical compositions of propolis samples vary between different samples (Rushdi et al., 2014). composition of phenolic constituents were different in the three kinds of ethanolic extract propolis and Egyptian propolis were contained more phenolic compounds than in the Chinese propolis and old wax comb extract (Kamel et al., 2013). Chemical compound differences of propolis are thus easily comprehended as it is a complex mixture of compounds gleaned from various plants and processed by salivary enzymes of bees. Therefore, composition of propolis depends of the plants, the seasons resins are collected, and the bee species. This chemical variety brought a crucial question of standardization, even bee do not change its chemical composition (Bankova et al., 2000). Propolis sample analyses from differences parts of the world have been collectively consists of over 300 different chemical compounds (Huang et al., 2014). It has been possible to identify several families of chemically active compounds through various, technics such as mass spectroscopy, nuclear magnetic resonance, gas chroma-tography coupled with mass spectroscopy, but not to define a minimal common composition with clear concentrations of the various compounds. Phenolic compounds include various acids such as cinnamic, p-coumaric, chicoric, caffeic and fulric acids (Bankova, 2005).

\section{REFERENCES}

1. Bankova V. 2005. Recent trends and important developments in propolis research. Evid. Based Complcm. Altern. Med. 2:29-32.

2. Bankova V.; R.; S. Popov; O. Pureb and G. Bocari .1994. Volatile constituents of propolis. Z Naturforsch Sect C. 49(1-2):6-10. 
3. Bankova V.; M. Popova; S. Bogdanov and A. G. Sabatini .2002. Chemical composition of European propolis: Expected and unexpected results. Z Naturforsch C. 5:530-533.

4. Bankova V. S.; S. L. de Castro and C. Marcucci Maria.2000. Propolis: recent advances in chemistry and plant origin. Apidologie 3-15.

5. Christov R.; B. Trusheva; M. Popova; V. Bankova and M. Bertrand. 2006. Chemical composition of propolis from Canada: its antiradical activity and plant origin. Nat. Prod. Res. 20, 531-536.

6. Ghisalberti E. L. 1979. Propolis: A review. Bee World 60:59-84

7. Hegazi A.; F. Abd El Hady and F. Abd Allah .2000. Chemical composition and antimicrobial activity of European propolis. Z Naturforsch. 55(1-2):70-75.

8. Huang W. Y.; Y. Z. Cai and Y. Zhang .2010. Natural phenolic compounds from medicinal herbs and dietary plants: potential use for cancer prevention. Nutr. Cancer; 62: 1-20.

9. Huang S.; C. -P. Zhang; K. Wang; G.Q. Li and F.-L. Hu 2014. Recent advances in the chemical composition of propolis. Mol. Basel Switz. 19, 19610-19632.

10. Ildenize BSCP; CHFS Alexandra; MC Fabio; TS Mario; CM Maria; TD Flavia; SP Giovanna and DOC Patricia.2004. Factors that Influence the Yield and Composition of Brazilian Propolis Extracts. J. Braz. Chem. Soc. 15(6):964-970.

11. Kamel, A. A.; A. A. Moustafa, and E. A. Nafea.2013. Propolis as a natural antibiotic to control American foulbrood disease in honey bee colonies. African J. Agr .Res. Vol. 8(23): 3047-3062.

12. Kartal M; S. Kaya and S. Kurucu .2002. GC-MS analysis of propolis samples from two different regions of Turkey. Z Naturforsch. 57:905-909.

13. Krell R.1996. Value-Added Products from Beekeeping. FAO Agricultural Services Bulletin No. 124, Food and Agriculture Organization of the United Nations, Rome, Italy, ISBN: 92-5-103819-8.

14. Kumazawa S.; J. Nakamura; M. Murase; M. Miyagawa; A. MR and S. Fukumoto .2008. Plant origin of Okinawan propolis: honeybee behavior observation and phytochemical analysis. Naturwissenschaften 95:781-786.

15. Piccinelli A.L.; C. Lotti; L. Campone; O. Cuesta-Rubio; M. Campo Fernandez and L. Rastrelli .2011. Cuban and Brazilian red propolis: botanical origin and comparative analysis by high-performance liquid chromatography-photodiode array detection/electrospray ionization tandem mass spectrometry. J. Agric. Food Chem. 59, 6484-6491.

16. Popova M.; V. Bankova; D. Butovska; V. Petkov;B.Nikolova-Damyanova; A.G. Sabatini; G.L. Marcazzan and S. Bogdanov.2004. Validated methods for the 
quantification of biologically active constituents of poplar-type propolis. Phytochem. Anal. PCA 15, 235-240.

17. Righi M.; C. Klinger; V. Eyring; J. Hendricks; A. Lauer and A. Petzold .2011. Climate impact of biofuels in shipping: global model studies of the aerosol indirect effect. Environ. Sci. Tech., 45, 3519-3525.

18. Rushdi A. I.; N. M. Adgaba; N. I. M.Bayaqoob; A. Al-Khazim; B. R. T. Simoneit; A. H. El-Mubarak and K. Al-Mutlaq .2014. Characteristics and chemical compositions of propolis from Ethiopia. SpringerPlus 3, 253-261.

19. Santos F.; E. Bastos; A. Maia; M. Used; M. Carvalho; I. Farias and E. Morcira .2003. Brazilian propolis: Pliysicochemical properties, plant origin and antibacterial activity on pcriodontopatlio gens. Phytother. Res. 17:285-289.

20. Sawaya A. C. H. F.; I. B. Cunha; M. Marcucci; R. F. de Oliveira Rodrigues and M. N. Eberlin . 2006. Brazilian propolis of tetragoniscaangustula and Apismellifera. Apidologie 398-407.

21. Sforcin J. M. and V. Bankova .2011. Propolis: Is there a potential for the development of drugs? J Ethnopharmacol 133:253-260.

22. Souza E. A.; R. Zaluski; N. Veiga and R.O. Orsi .2016. Effects of Seasonal Variations and Collection Methods on the Mineral Composition of Propolis from Apismelliferalinnaeus Beehives. Brazilian Journal of Biology, 76, 396-401. 


\section{مقارنة بين بعض مركبات البروبوليس الفينولية فى مصر}

\section{أيمن محمد محمد غنيه1 ، نجلاء الأحمدي غزاله1 ، محمدعلي إبراهيم عبدالعظيم

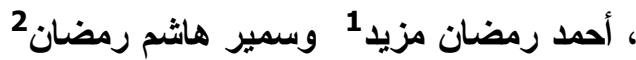

1-قسم بحوث النحل - معهة بحوث وقاية النباتات-مركز البحوث الزر اعية-الدقى-جيزة-مصر. 2- مملكة النحل المصرية- كلبة الزراعه - جامعة عين شمس.

تم اختبار عينات من البروبوليس جمعت من مناطق مختلفة من مصر اضافة الى بروبوليس تجارى صينى وذلك لتحديد المركبات الفينولية الموجودة فى كل منها وذللك باستخدام جهاز التحليل

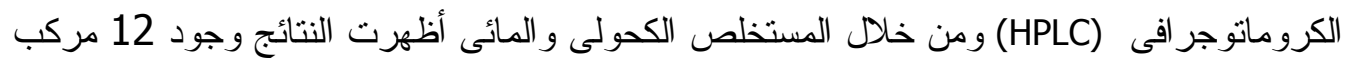
فينولى على الأكثر فى العينات المختبرة موزعة بينهم بتركيزات ونسب مختلفة. أظهر مركب وجوده بنسبة عالية فى البروبوليس المجموع من محافظة كفر الثيخ (80\%) بليه

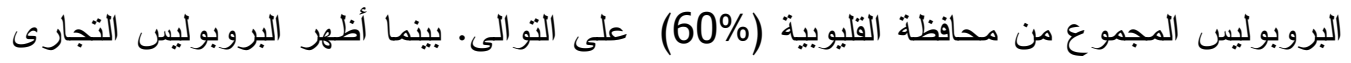

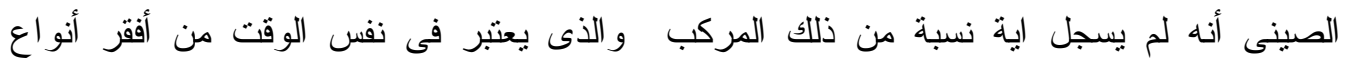

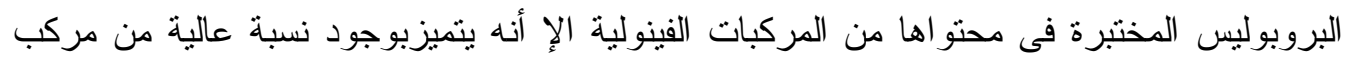

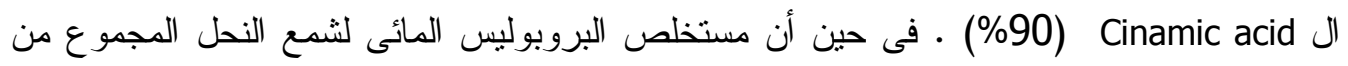
أقر اص النحل القديم أنثبت وجود كميات قليلة من ال 12 مركب فينولى المسجلة وكان أعلاهم هومركب Benzoic acid (160). 